\title{
高温域における $\mathrm{Cr}_{2} \mathrm{O}_{3}$ の炭素還元
}

$\begin{array}{ccccccc}\text { 下 } & \text { 尾 } & \text { 聰 } & \text { 夫* 岡 } & \text { 本 龍 幸** } \\ & \text { 安 } & \text { 藤 } & & \text { 繁* } & \text { 木 村 } & \text { 弘* }\end{array}$

J.Japan Inst.Metals, Vol.51,No.12(1987),pp.1145-1151

Reduction of $\mathrm{Cr}_{2} \mathrm{O}_{3}$ with Solid Carbon at High Temperatures

Toshio Shimoo*, Tatsuyuki Okamoto**, Shigeru Ando* and Hiroshi Kimura*

The rate of reduction of $\mathrm{Cr}_{2} \mathrm{O}_{3}$ by solid carbon has been investigated at high temperature from 1743 to $1993 \mathrm{~K}$, and under an argon atmosphere. The rate of reduction has been determined from the mass loss measured by means of the thermo-balance. The physical situation of the reduction product has been examined by microscopic observation.

The powder of $\mathrm{Cr}_{2} \mathrm{O}_{3}$ in a graphite crucible as a reductant was hardly reduced, when the reduction product was solid carbide. The reduction was accelerated by continuous formation of $\mathrm{Cr}-\mathrm{C}$ melt at high temperatures.

The reduction rate of $\mathrm{Cr}_{3} \mathrm{O}_{3}$ by powdered graphite decreased with increasing the particle sizes of both $\mathrm{Cr}_{2} \mathrm{O}_{3}$ and graphite. In the case of fine powder of $\mathrm{Cr}_{2} \mathrm{O}_{3}$, the reduction product was formed around the graphite particle. The reduction was controlled by the diffusion of carbon or chromium in the product layer. The reduction of coarse particle of $\mathrm{Cr}_{2} \mathrm{O}_{3}$ proceeded topochemically and the graphite particle was not coated by the product. The reduction rate was analysed by means of the equation for rate controlled by gas diffusion through the porous product layer formed around $\mathrm{Cr}_{2} \mathrm{O}_{3}$.

(Received April 3, 1987)

Keywords: reduction of $\mathrm{Cr}_{2} \mathrm{O}_{3}$, solid carbon, high temperatures, themogravimetry, reaction kinetics, rate-determining step

I. 緒言

クロム鉱石の溶融還元によるフェロクロムおよび $\mathrm{Fe}$ Cr 合金の製造プロセスの開発が試みられている.しかし 溶融還元挙動について十分に解明されているとは言えない のが現状であり，とくにその基礎反応について詳細に調べ る必要がある。乙の観点から, 著者らはスラグ中酸化クロ ムの固体炭素による還元の反応機構について検討してき $た^{(1)-(4)}$.

溶融還元製錬法の一つとして，鉱石および炭材の粉末吹 き込み法による還元が試みられている．乙の場合, 溶融還 元域の高温に抢けるクロム鉱石の炭素還元についての知見 が必要とされている．クロム鉱石はクロマイトを主成分 とし, 脈石成分として $\mathrm{MgO}, \mathrm{Al}_{2} \mathrm{O}_{3}$ 等を含有していて, 複雑な組成および構造を有するので, 炭素還元機構の解明 には多くの困難を伴うと考えられる．したがって，まず クロム鉱石の基本成分である $\mathrm{Cr}_{2} \mathrm{O}_{3}$ の炭素還元という単
純な反応系を設定し, その反応機構について明らかにする ことにした．従来より， $\mathrm{Cr}_{2} \mathrm{O}_{3}$ の炭素還元については数 多くの研究報告があり, 真空中 ${ }^{(5)-(7)}$ あるいは大気圧下 ${ }^{(8)}$ で検討されてきたが，いずれも比較的低温における固相還 元に関するあのである.

本研究では $1743 \mathrm{~K}$ ～ $1993 \mathrm{~K}$ の高温域抢よび Ar 雾囲気 中に打いて $\mathrm{Cr}_{2} \mathrm{O}_{3}$ 粉末の炭素還元速度を測定し，とくに 溶融還元温度域での反応機構について検討した。

\section{II. 実 験 方 法}

試料の $\mathrm{Cr}_{2} \mathrm{O}_{3}$ 粉末は平均粒径 $3 \times 10^{-7} \mathrm{~m}$ の試薬特級品 である。なお $\mathrm{Cr}_{2} \mathrm{O}_{3}$ 粒径の影響を調べる実験では上記粉 末を $98 \mathrm{MPa}$ の圧力で加圧成形し，1873 K で焼結したも のを粉砕して得た平均粒径 $1.5 \times 10^{-4}, 3.7 \times 10^{-4}$ および $7.8 \times$ $10^{-4} \mathrm{~m}$ のものを使用した。還元剤は平均粒径 $5.8 \times 10^{-5} \mathrm{~m}$ に粉砕した灰分 $0.1 \%$ 以下の人造黒鉛を用いた。黒鉛粒径 の影響を調べる場合， $1.5 \times 10^{-5}, 7.1 \times 10^{-5}$ および $13.6 \times$

* 大阪府立大学工学部(College of Engineering, University of Osaka Prefecture, Sakai)

** 大阪府立大学大学院生 (Graduate Student, University of Osaka Prefecture, Sakai) 
$10^{-5} \mathrm{~m}$ のむのも実験に供した。実験は二通り行なった。 $\mathrm{Cr}_{2} \mathrm{O}_{3}$ 粉末のみを黒鉛るつぼに入れて還元する実験抢よ び $\mathrm{Cr}_{2} \mathrm{O}_{3}$ と黒鉛粉末の混合物の還元実験である.乙の混 合物は粉末をメタノールでスラリー状にし, 十分に擋拌混 合したものである．炭素配合比の影響を調べる実験以外は， $20 \% \mathrm{C}$ (質量百分率)の試料を用いた。

実験装置はタンマン炉と自動電子天秤(秤量 $100 \mathrm{~g}$, 感 量 $0.1 \mathrm{mg}$ ) から成っている. 測定雾囲気は Arであり, 炉 底より $2.5 \times 10^{-5} \mathrm{~m}^{3} / \mathrm{s}$ の流量で流通させた. $\mathrm{Cr}_{2} \mathrm{O}_{3}$ 量が 5 $\mathrm{g}$ となるように秤量した試料を黒鉛るつぼ(内径 $26 \mathrm{~mm}$, 深さ $50 \mathrm{~mm}$ ) に入れて天秤に接続し, 所定温度に調整した 炉均熱部に吊す. $\mathrm{Cr}_{2} \mathrm{O}_{3}$ 還元に伴う $\mathrm{CO}$ 発生による質量 減少量を連続測定して，還元曲線を求めた。な挴回の測 定以前に空るつぼを用いてブランク值を測定したが，その 值は無視しえた．測定終了後の試料は還元生成物の顕微鏡 観察および化学分析に供した。

\section{III. 実 験 結 果}

熱力学的検討によると, $\mathrm{Cr}_{2} \mathrm{O}_{3}$ と固体炭素との反応に よる還元生成物は温度および雾囲気の $P_{\mathrm{CO}_{2}} / P_{\mathrm{CO}}$ 比に応 じて変化する ${ }^{(9)}$. 本実験条件は Ar 雾囲気であり，また 1743 K〜 $1993 \mathrm{~K}$ の高温域である.乙のような場合には, 高温 である程, 順次 $\mathrm{Cr}_{7} \mathrm{C}_{3}, \mathrm{Cr}_{23} \mathrm{C}_{6}$ の炭化物扝よび金属 $\mathrm{Cr}$ が 生成され易くなる.

$\mathrm{Cr}_{2} \mathrm{O}_{3}$ と黒鉛との接触点に扣いて直接還元が開始する が, 一旦 CO が形成されると, 以後の還元は気相を介して 進行すると考えられる.すなわちソリューション・ロス反 応を伴う見掛け上の直接還元が進行するようになる。

$$
\begin{aligned}
7 \mathrm{Cr}_{2} \mathrm{O}_{3}(\mathrm{~s})+33 \mathrm{CO}(\mathrm{g}) & =2 \mathrm{Cr}_{7} \mathrm{C}_{3}(\mathrm{~s})+27 \mathrm{CO}_{2}(\mathrm{~g}) \\
23 \mathrm{Cr}_{2} \mathrm{O}_{3}(\mathrm{~s})+93 \mathrm{CO}(\mathrm{g}) & =2 \mathrm{Cr}_{23} \mathrm{C}_{6}(\mathrm{~s})+81 \mathrm{CO}_{2}(\mathrm{~g}) \\
\mathrm{Cr}_{2} \mathrm{O}_{3}(\mathrm{~s})+3 \mathrm{CO}(\mathrm{g}) & =2 \mathrm{Cr}(\mathrm{s})+3 \mathrm{CO}_{2}(\mathrm{~g}) \\
\mathrm{C}(\mathrm{s})+\mathrm{CO}_{2}(\mathrm{~g}) & =2 \mathrm{CO}(\mathrm{g})
\end{aligned}
$$

いずれにせよ, 総括的には反応の化学量論的関係から, $\mathrm{Cr}_{2} \mathrm{O}_{3}$ の還元率 \%R は式( 5 )によって表わされる.

$\% R=\left\{W_{\mathrm{m}} \cdot\left(M_{\mathrm{Cr}_{2} \mathrm{O}_{3}} / 3 M_{\mathrm{CO}}\right) / W_{\mathrm{Cr}_{2} \mathrm{O}_{3}}\right\} \times 100$

ここに, $W_{\mathrm{m}}$ : 熱天秤で測定した系の質量減少量

$$
M_{\mathrm{i}} \text { : 成分 } \mathrm{i} \text { の分子量 }
$$

$W_{\mathrm{Cr}_{2} \mathrm{O}_{3}}$ : 初期試料中の $\mathrm{Cr}_{2} \mathrm{O}_{3}$ の質量

$\% R$ と反応時間との関係によって表わした還元曲線を用 いて，実験結果を評価した。

\section{1. 黒鉛るつぼ中での $\mathrm{Cr}_{2} \mathrm{O}_{3}$ の還元}

$\mathrm{Cr}_{2} \mathrm{O}_{3}$ 粉末のみを黒鉛るつぼに入れて, $1793 \mathrm{~K}$ 1993 $\mathrm{K}$ の各温度に保持して還元を行なった結果を Fig. 1 に示 す．還元速度におよぼす温度の影響は非常に大きい. 1793 $\mathrm{K}$ では還元の進行は緩慢であり, $10.8 \mathrm{ks}$ 後においても僅 か \% $R=7.0$ に過ぎない.なお図示しなかったが, 1743 Kに打いては還元はほとんど進行していない. $1893 \mathrm{~K}$ で

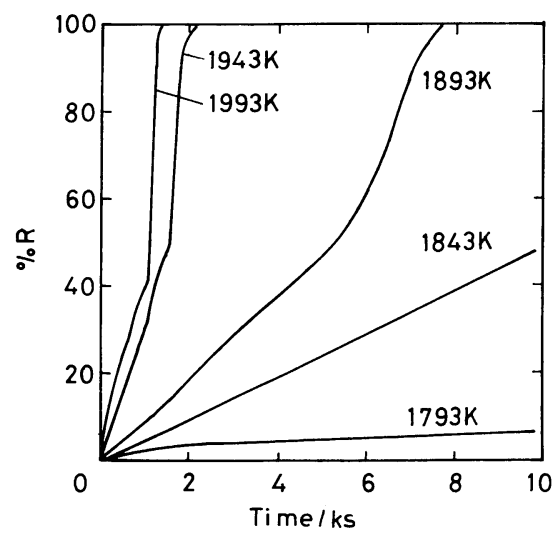

Fig.1 Reduction curves of $\mathrm{Cr}_{2} \mathrm{O}_{3}$ at various temperatures.

は約 $\% R=50$ において還元曲線は屈曲し, それ以後にお いて還元が促進されている．高温である程，屈曲点は低還 元率へ移行している. $1993 \mathrm{~K}$ に拉いては僅か $1.3 \mathrm{ks}$ の短 時間で $\% R=100$ に達している.

測定終了後の試料断面の観察結果によると, るつぼ底は 激しく侵食されていて金属光沢を有する生成物が存在して いた. したがって融体を生じながら $\mathrm{Cr}_{2} \mathrm{O}_{3}$ 還元が進行し ていることは明らかである。

Fig. 2 は還元生成物の顕微鏡写真を示す. $1793 \mathrm{~K}$ およ び $1843 \mathrm{~K}$ では, 試料は収縮しスポンジ状となり，るつぼ 底から容易に剥離した，黒鉛に密着した白色の層は還元生 成物である. $1793 \mathrm{~K}$ では \% $R=7.0$ と低還元率であるた めに, 生成物は薄く不連続な層となっている。 $1893 \mathrm{~K}$ で は生成物層が未還元層亡複雑に入り組んでいる.

黒鉛が炭化物で覆われると, 式(4)の反応に代って下記 の反応が起る.

$$
\begin{gathered}
\mathrm{Cr}_{7} \mathrm{C}_{3}(\mathrm{~s})+3 \mathrm{CO}_{2}(\mathrm{~g})=7 \mathrm{Cr}(\mathrm{s})+6 \mathrm{CO}(\mathrm{g}) \\
\mathrm{Cr}_{23} \mathrm{C}_{6}(\mathrm{~s})+6 \mathrm{CO}_{2}(\mathrm{~g})=23 \mathrm{Cr}(\mathrm{s})+12 \mathrm{CO}(\mathrm{g})
\end{gathered}
$$
したがって $\mathrm{Cr}$ 炭化物之金属 $\mathrm{Cr}$ が共存する状態となる. Cr-C 系状態図 ${ }^{(10)}$ によと, 約 $1783 \mathrm{~K}$ において炭化物之 $\mathrm{Cr}$ は共晶溶融する. $1893 \mathrm{~K}$ で得られた還元生成物の炭素 分析值は 4.1〜 4.7\% であり, 共晶組成に近い。したがっ て生成物は溶融していて, $\mathrm{Cr}-\mathrm{C}$ 溶体中炭素による還元が 進行する.

$$
\mathrm{Cr}_{2} \mathrm{O}_{3}(\mathrm{~s})+3 \underline{\mathrm{C}}(\text { in } \mathrm{Cr}-\mathrm{C} \text { melt })=2 \underline{\mathrm{Cr}}+3 \mathrm{CO}(\mathrm{g})
$$
黒鉛るつぼ中で $\mathrm{Cr}_{2} \mathrm{O}_{3}$ を還元する場合, $\mathrm{Cr}-\mathrm{C}$ 融体の生 成が大きな影響をおよぼす．融体が存在しえない $1743 \mathrm{~K}$ では, 事実上還元は進行しなかった。一方 $1943 \mathrm{~K}$ 以上の 高温では, 融体が早期にかつ十分に生成されるために還元 が著しく促進される(Fig.1). また溶融状態を維持するた めには，還元に消費される融体中炭素がるつぼ壁から供給 される必要があるので, この点からあ高温を必要とする. とてろで $\mathrm{Cr}_{2} \mathrm{O}_{3}$ の高温還元は $\mathrm{Fe}_{2} \mathrm{O}_{3}$ のそれと反応機構が 大きく異なっている ${ }^{(11)} . \mathrm{Fe}_{2} \mathrm{O}_{3}$ の還元では中間生成物の 


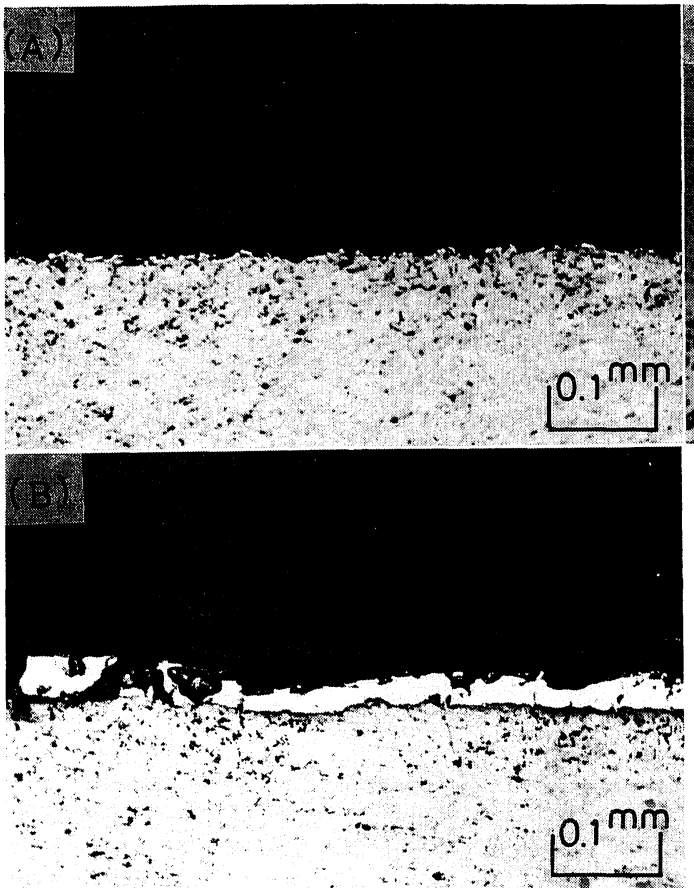

$\mathrm{FeO}$ が約 $1673 \mathrm{~K}$ で溶融するために, 酸化物融体の固体炭 素による還元として進行する.

\section{2. $\mathrm{Cr}_{2} \mathrm{O}_{3}$ と黒鉛粉末の混合試料の還元}

上述の還元方式では $\mathrm{Cr}_{2} \mathrm{O}_{3}$ と黒鉛との接触状態が悪く, 速やかな $\mathrm{Cr}_{2} \mathrm{O}_{3}$ 還元を達成するためには，還元生成物が 溶融状態を維持しうる高温を必要とした. $\mathrm{Cr}_{2} \mathrm{O}_{3}$ と炭素 粉末の混合試料を用いた実験では，例えば $1273 \mathrm{~K}$ の低温 においても還元が進行している(8). 以下に混合試料を用い て $1743 \mathrm{~K}$ 以上の高温での還元実験を行なった.

$\mathrm{Cr}_{2} \mathrm{O}_{3}$ と炭素粉末の混合試料と乙れを $98 \mathrm{MPa}$ の圧力 で圧粉成形して得られたタブレット(直径 $20 \mathrm{~mm}$ ) につい て，還元性の比較を行なった。いずれの試料あ質量は 6.25 $\mathrm{g}$ であり，炭素配合率は $20 \%$ (質量百分率)である. 両者 の還元曲線を Fig. 3 亿示す．還元曲線の形状はジグモイ ド型であり, 誘導期, 促進期および停滞期の 3 期から成っ ている.な扣高温での還元であるために, 誘導期は極く短 時間に過ぎない。しかし後に示すように，実験条件によっ ては誘導期が長時間におよぶ場合ああった。粉末と圧粉体 試料との間において，還元速度の差はほとんど存在してい ない，とくに反応初期ではタブレット試料はるつぼ底の一 部と接触しているのみで, 一方粉末試料はるつぼ壁とも接 触しているので, 後者のるつぼとの接触面積は著しく大き い. しかし還元曲線に差が認められないてとは黒鉛るつぼ との反応が無視できて，専ら試料に配合した黒鉛粒子との 反応によって $\mathrm{Cr}_{2} \mathrm{O}_{3}$ 還元が進行しているてとになる．以 下の還元実験はすべて粉末試料を用いて行なった.

Fig.4 および 5 は還元速度におよぼす試料中炭素配合率

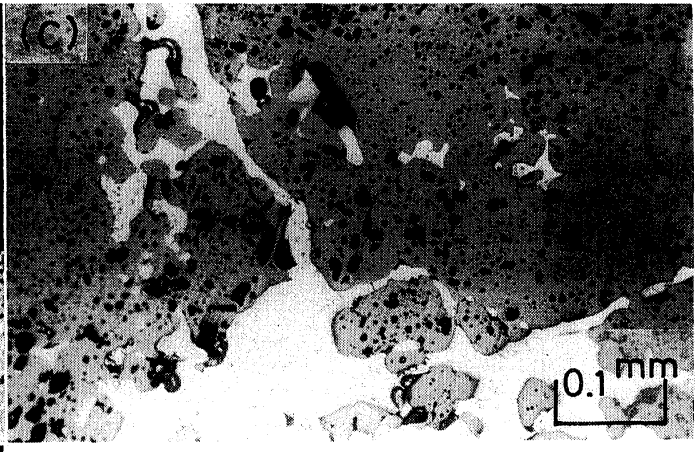

Fig.2 Optical micrographs of reduced samples.

(A) $1793 \mathrm{~K}, 10.8 \mathrm{ks} . \% R=7.0$.

(B) $1843 \mathrm{~K}, 10.8 \mathrm{ks}, \% R=53.1$.

(C) $1893 \mathrm{~K}, 5.4 \mathrm{ks}, \% R=51.9$.

Dark areas of photos (A), (B) was filled with resin.

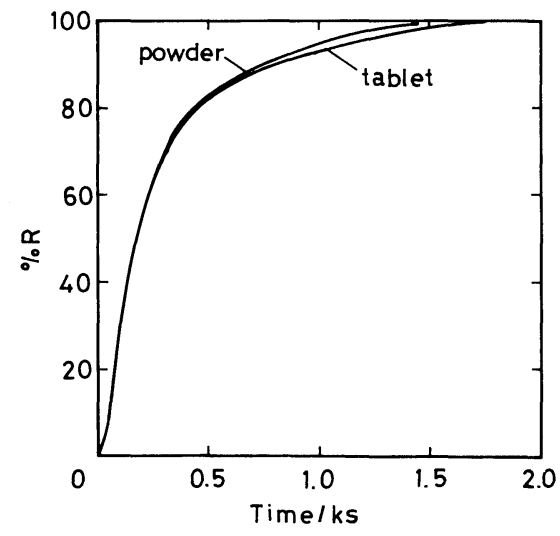

Fig.3 Reduction curves of powder and tablet of $\mathrm{Cr}_{2} \mathrm{O}_{3}-\mathrm{C}$ mixtures at $1893 \mathrm{~K}$.

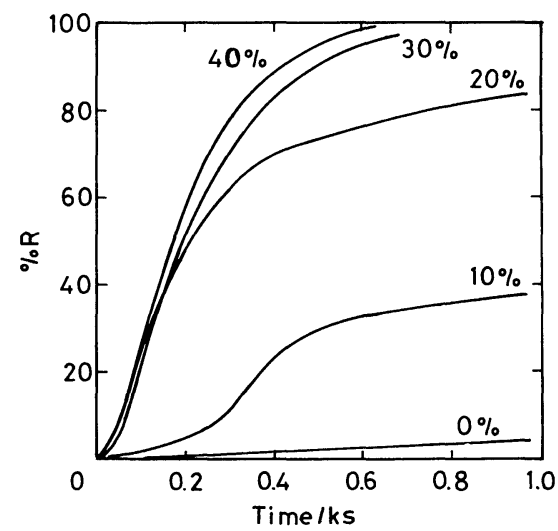

Fig.4 Effect of carbon percentage in sample on reduction rate of $\mathrm{Cr}_{2} \mathrm{O}_{3}$ at $1843 \mathrm{~K}\left(r_{\mathrm{o}}=3 \times 10^{-7} \mathrm{~m}\right.$, $\left.r_{\mathrm{c}}=5.8 \times 10^{-5} \mathrm{~m}\right)$. 


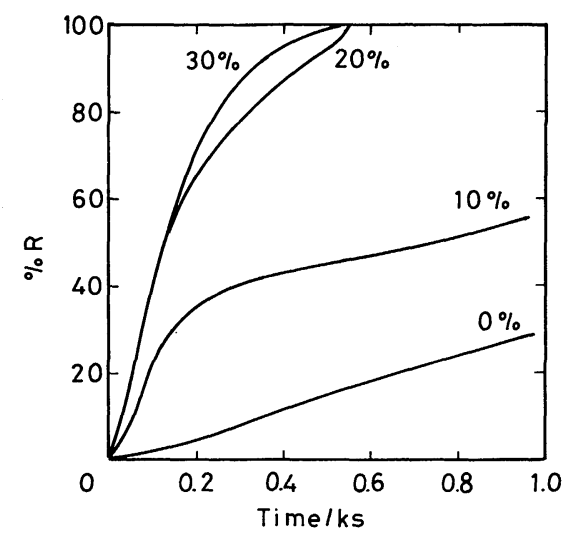

Fig.5 Effect of carbon percentage in sample on reduction rate of $\mathrm{Cr}_{2} \mathrm{O}_{3}$ at $1943 \mathrm{~K}\left(r_{\mathrm{o}}=3 \times 10^{-7} \mathrm{~m}\right.$, $\left.r_{\mathrm{c}}=5.8 \times 10^{-5} \mathrm{~m}\right)$.

(質量百分率)の影響を示す．0\%における結果は黒鉛るつ ぼ壁との反応による還元が非常に遅いことを意味してい る.とくに $1843 \mathrm{~K}$ の低温では, 測定時間内に扔いてはジ グモイド型還元曲線の誘導期にとどまっている．炭素配合 率が増加すると，誘導期が短くなるとともに還元が促進さ れている. 各実験温度で生成しうる炭化物 $\mathrm{Cr}_{7} \mathrm{C}_{3}$ 打よび $\mathrm{Cr}_{23} \mathrm{C}_{6}$ に対する黒鉛粉末の当量配合比はそれぞれ $23.3 \%$ および $21.8 \%$ である. 図より $20 \%$ 程度までは黒鉛配合量 の増加によって還元は著しく促進されている。しかし上記 当量配合比以上の過剩配合はほとんど速度に影響をおよぼ さない. $1843 \mathrm{~K}$ (Fig.4)では測定終了後の試料はすべて収 縮した焼結体状となり，るつぼ底とのみ接触していて容易 に剥離した。一方 1943 K(Fig.5)では炭素配合率 20\% 以 下の試料の還元生成物は溶融し, るつぼ底に強く凝固付着 していた．配合黒鉛の残留している $30 \%$ 試料の還元生成 物の性状は $1843 \mathrm{~K}$ の場合之同様である.

Fig. 6 は温度の影響を示す。試料中炭素配合率は $20 \%$ である，当然ながら，高温であるほど還元は速やかに進行

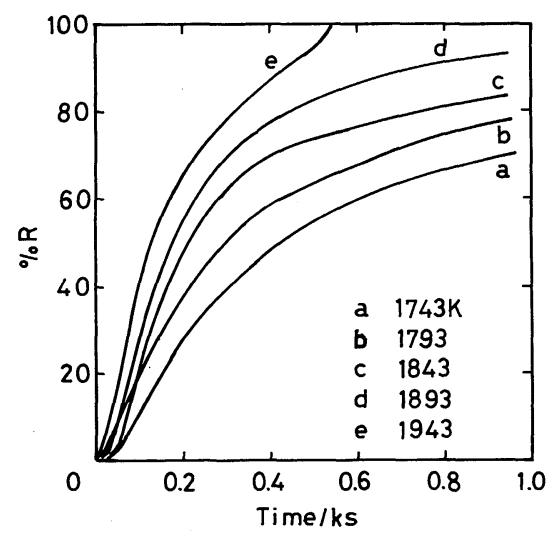

Fig.6 Reduction curves of $\mathrm{Cr}_{2} \mathrm{O}_{3}$ with carbon at various temperatures $\left(r_{\mathrm{o}}=3 \times 10^{-7} \mathrm{~m}, r_{\mathrm{c}}=5.8 \times 10^{-5}\right.$ $\mathrm{m})$.
し，誘導期あ短縮されている．\%R=100 の時点で， 1843 $\mathrm{K}$ 以下の試料はスポンジ状となり，また $1893 \mathrm{~K}$ 以上の還 元生成物は融体となっていた。

還元速度におよぼす $\mathrm{Cr}_{2} \mathrm{O}_{3}$ および黒鉛粒径の影響をそ れぞれ Fig.7および 8 に示す.いずれの場合す粒径の増 加は還元速度を遅くする．同様な結果は他の反応系におい ても得られている( ${ }^{(8)(12)}$.

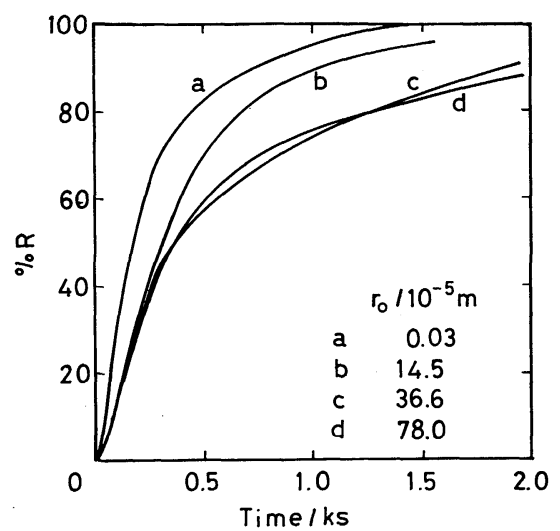

Fig.7 Effect of particle size of $\mathrm{Cr}_{2} \mathrm{O}_{3}, r_{\mathrm{o}}$ on reduction rate at $1893 \mathrm{~K}\left(r_{\mathrm{c}}=5.8 \times 10^{-5} \mathrm{~m}\right)$.

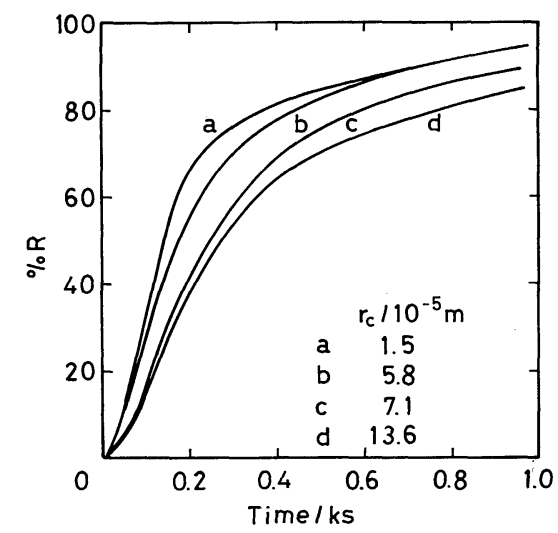

Fig.8 Effect of particle size of carbon, $r_{c}$ on reduction rate at $1893 \mathrm{~K}\left(r_{\mathrm{o}}=3 \times 10^{-7} \mathrm{~m}\right)$.

\section{IV. 考 察}

$\mathrm{Cr}_{2} \mathrm{O}_{3}$ と黒鉛配合試料の還元について, 反応機構の検 討拈よび速度解析を行なう。

Fig. 9 は $1893 \mathrm{~K}$ 亿打ける還元生成物の顕微鏡写真を示 す. 微細な $\mathrm{Cr}_{2} \mathrm{O}_{3}$ 試料 $\left(\gamma_{\mathrm{o}}=3 \times 10^{-7} \mathrm{~m}\right)$ 之粗粒試料 $\left(\gamma_{\mathrm{o}}=\right.$ $\left.7.8 \times 10^{-4} \mathrm{~m}\right)$ とでは, 還元生成物の状態は全く異なってい る.すなわち微細試料の場合には主として黒鉛粒の周囲に 白色の還元生成物が形成されていて，還元の進行とともに 黒鉛粒径が減少し生成物層が厚くなっている。な扔 $\mathrm{Cr}_{2} \mathrm{O}_{3}$ 粒と黒鉛粒を擋拌混合する際に生じた黒鉛微粒子は早期に 

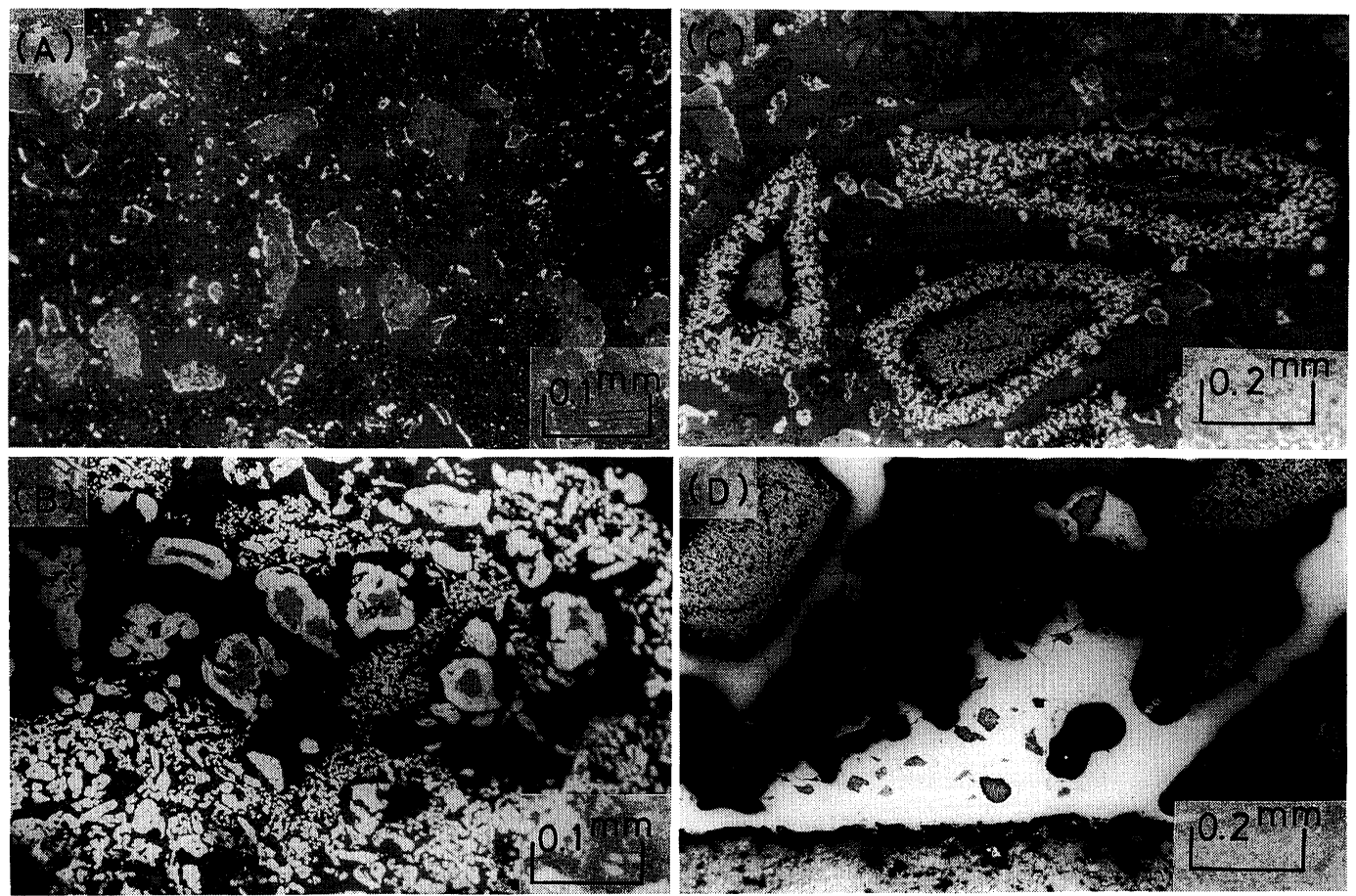

Fig.9 Optical micrographs of reduced samples. (A) $r_{\mathrm{o}}=3 \times 10^{-7} \mathrm{~m}, r_{\mathrm{c}}=5.8 \times 10^{-5} \mathrm{~m}, \% R=25$. (B) $r_{\mathrm{o}}=3 \times 10^{-7} \mathrm{~m}, r_{\mathrm{c}}=5.8 \times 10^{-5} \mathrm{~m}, \% R=75$. (C) $r_{\mathrm{o}}=7.8 \times 10^{-4} \mathrm{~m}, r_{\mathrm{c}}=5.8 \times 10^{-5} \mathrm{~m}, \% R=50$. (D) $r_{\mathrm{o}}=7.8 \times 10^{-4} \mathrm{~m}, r_{\mathrm{c}}=5.8 \times 10^{-5} \mathrm{~m}, \% R=75$. gray particle : graphite, white phase : carbide, dark gray particle : $\mathrm{Cr}_{2} \mathrm{O}_{3}$. Carbide is formed around graphite particle in photo $(\mathrm{A})$ and around $\mathrm{Cr}_{2} \mathrm{O}_{3}$ particle in phote (C), respectively. Space between particles was filled with resin.

酸化消滅し，微細な白色の還元生成物となって点在してい る(A). てのような還元状況は以下のように説明できる. 黒鉛粒と比較して $\mathrm{Cr}_{2} \mathrm{O}_{3}$ 粒は著しく微細であるので, 黒鉛粒の周囲に多数の $\mathrm{Cr}_{2} \mathrm{O}_{3}$ 粒子が取り巻いている．接 触点で開始する直接還元および以後のガス還元によって生 成した炭化物は黒鉛粒を被覆するととになる。

$\% R=75$ の時点では, 生成物は緻密であり, 滑らかな 面を形成しているので，半溶融状態近くなっていると思わ れる(Fig.9(B)).な打\% $R=100$ では完全に溶融し, 生 成物はるつぼ底に存在していた。

一方, 粗粒試料では $\mathrm{Cr}_{2} \mathrm{O}_{3}$ 粒子の周囲に白色の還元生 成物層が存在していて, トポケミカルに還元が進行してい る. $\% R=50$ では生成物層は多孔質であり, また大部分 の黒鉛粒子は炭化物によっては覆われていないで露出して いる $(\mathrm{C}) . \% R=75$ まで還元された状態では, $\mathrm{Cr}_{2} \mathrm{O}_{3}$ 粒 子に付着している生成物層は緻密であり，一部にはるつぼ 底に溶融滴下しているのが観察された $(\mathrm{D})$.

Fig.9(A), (B) と同一試料 (20\% C 配合)を $1893 \mathrm{~K}$ で還 元した場合の生成物中炭素濃度は $\% R=50,75$ および 100 の還元率においてそれぞれ $13.8,8.2$ および $3.3 \%$ と定量 された．還元の進行とともに濃度は減少していて，試料中 黒鉛粒子が還元に消費されている％ \% $\%=100$ における炭 素濃度 $3.3 \%$ の $\mathrm{Cr}-\mathrm{C}$ 合金は $1893 \mathrm{~K}$ 亿扔いて溶融してい $3^{(10)}$.
以上の結果から, 次の反応機構が考えられる. 本実験条 件下で生成しうる炭化物 $\mathrm{Cr}_{7} \mathrm{C}_{3}$ 扔よび $\mathrm{Cr}_{23} \mathrm{C}_{6}$ の当量配合 比はそれぞれ 23.3 执よび $21.8 \% \mathrm{C}$ である. この值以下の 配合比率の試料では $\% R=100$ 亿達する以前に炭素粒子 を消費し尽すととになる．したがって，それ以後では式 (1)と (6)あるいは式 (2)と ( 7 )の反応の組み合わせによ る連続反応が進行して, 生成物中炭素を減じるととになる. 粗粒の $\mathrm{Cr}_{2} \mathrm{O}_{3}$ 還元の場合には，乙の状況が概和該当する 之思われる。しかし微細な $\mathrm{Cr}_{2} \mathrm{O}_{3}$ の場合, 炭素の周囲は 炭化物によって覆われるので, 炭素が残留していてあ比較 的早期より上記連続反応に基づいて $\mathrm{Cr}_{2} \mathrm{O}_{3}$ の還元が進行 する.

金属クロム製造を目的とした炭素還元の研究によると， 反応初期には炭化物を生じるが, 後期になると炭化物と $\mathrm{Cr}_{2} \mathrm{O}_{3}$ との間に扔いて反応が進行するようになる ${ }^{(13)-(15)}$. 後者の反応については同様な気相を介した機構が考えられ ている.

$\mathrm{Cr}$ と炭化物は約 $1773 \mathrm{~K}$ で共晶溶融する(10)ので, 最終 的に還元生成物は融体之なり，とくに高温では生成物粒子 が凝集して滴下し，るつぼ底に溜っていた．30\%炭素の 試料では $\% R=100$ においてあ炭素粒子が残留している ので, $1893 \mathrm{~K}$ の高温でも生成物は溶融しないで, スポン ジ状を呈していた.

微細な $\mathrm{Cr}_{2} \mathrm{O}_{3}$ 試料と粗粒試料では反応機構が全く相違 
している．微細試料では炭素粒の周囲に緻密な生成物層か 形成され，式(1)と（6)あるいは (2)と( 7 )の反応の組み 合わせによって還元が進行する.Fig.4, 5 および 8 の結果 はいずれむ律速過程が式 $(6)$ ，( 7 )の反応側にあるととを 示唆する. 次の諸過程が考えられる.

(i ) 粒子間気孔を通しての $\mathrm{CO}, \mathrm{CO}_{2}$ の移動

(ii) 生成物層に打りる $\mathrm{C}, \mathrm{Cr}$ の移動

(iii) 界面反応, 式 (6), ( 7 )

$\mathrm{Cr}_{2} \mathrm{O}_{3}$ の還元反応は ( ii )の固相拡散の過程によって律速 されている可能性が大きい，乙の場合，放物線則が適用で きて，球形試料では次式が成立する.

$$
\left\{1-(1-x)^{1 / 3}\right\}^{2}=k_{\mathrm{c}}^{\prime} \cdot t
$$

こてに $k_{\mathrm{c}}^{\prime}$ は定数であり，また $x$ は炭素粒の反応率である. $x は$ 炭化物生成反応の化学量論より計算した。炭化物とし て $\mathrm{Cr}_{7} \mathrm{C}_{3}$ 抢よび $\mathrm{Cr}_{23} \mathrm{C}_{6}$ の両者が考えら机るので，化学 量論比として平均値を用いた。

$$
\begin{gathered}
23 \mathrm{Cr}_{2} \mathrm{O}_{3}(\mathrm{~s})+81 \mathrm{C}(\mathrm{s})=2 \mathrm{Cr}_{23} \mathrm{C}_{6}(\mathrm{~s})+69 \mathrm{CO}(\mathrm{g}) \\
7 \mathrm{Cr}_{2} \mathrm{O}_{3}(\mathrm{~s})+27 \mathrm{C}(\mathrm{s})=2 \mathrm{Cr}_{7} \mathrm{C}_{3}(\mathrm{~s})+21 \mathrm{CO}(\mathrm{g}) \\
x=W_{\mathrm{m}} \cdot\left(81 M_{\mathrm{C}} / 69 M_{\mathrm{CO}}+27 M_{\mathrm{C}} / 21 M_{\mathrm{Co}}\right) / 2 W_{\mathrm{C}}
\end{gathered}
$$

ここに $W_{\mathrm{C}}$ は初期試料中に配合された炭素の質量である。

Fig.6に示した結果に対して式(9)の速度式を適用した のが Fig.10である．いずれのプロットもかなり広範囲に 直線性が成立している．各直線は原点を通らずに，90１50 $\mathrm{s}$ の間で時間軸と交差している．てれは還元の誘導期に相 当すると考えられる. 高温の場合, 反応率が大きくなると プロットは直線関係から上方へ湾曲している．乙れは生成 物が溶融，離脱するようになるためと推定される.

Fig.11は $k_{\mathrm{c}}^{\prime}$ のアルレニウス・プロットを示す. 良好 な直線関係を満足していて，乙れより見掛けの活性化工 ネルギーを求めると $239 \mathrm{~kJ} / \mathrm{mol}$ である. とてろで $\mathrm{CaO}$ $\mathrm{Al}_{2} \mathrm{O}_{3}-\mathrm{Cr}_{2} \mathrm{O}_{3}$ 系スラグの炭素還元 ${ }^{(2)}$ 亿扔いて, 黒鉛に密 着した緻密な生成物層が形成されている場合，放物線則が 適用できることを示した。また活性化エネルギーとして $229 \mathrm{~kJ} / \mathrm{mol}$ が得られた. 上記本実験值はこの値とほぼ等

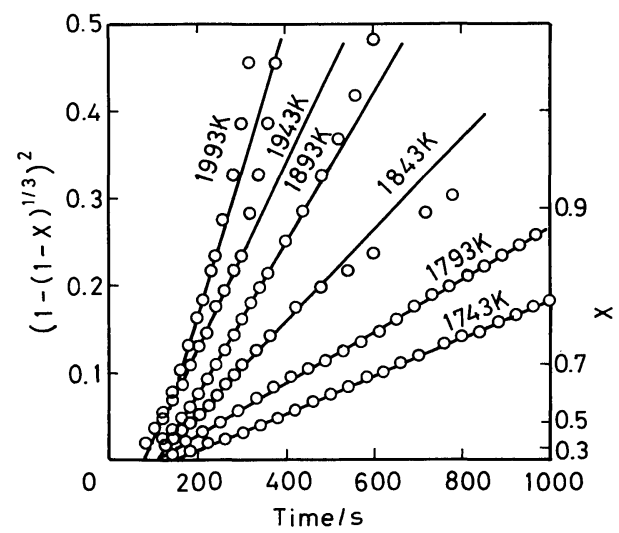

Fig.10 $\left(1-(1-x)^{1 / 3}\right)^{2}$ vs time plots at various temperatures $\left(r_{\mathrm{o}}=3 \times 10^{-7} \mathrm{~m}, r_{\mathrm{c}}=5.8 \times 10^{-5} \mathrm{~m}\right)$.

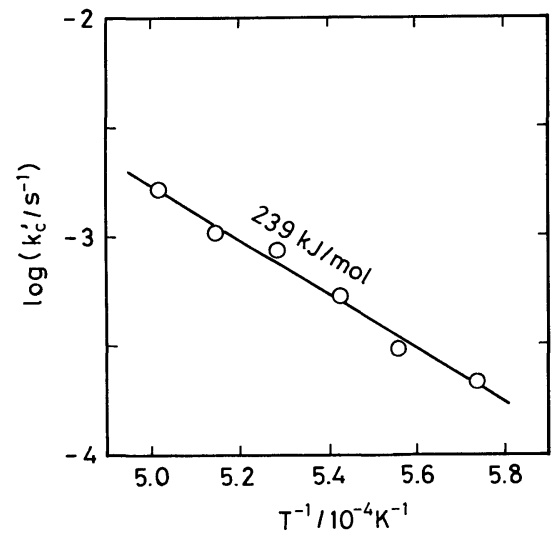

Fig.11 Temperature dependence of rate constant, $k_{\mathrm{c}}^{\prime}\left(r_{\mathrm{o}}=3 \times 10^{-7} \mathrm{~m}, r_{\mathrm{c}}=5.8 \times 10^{-5} \mathrm{~m}\right)$.

しい. さらに $\mathrm{Cr}$ 炭化物中の拡散の活性化エネルギー 167〜 $188 \mathrm{~kJ} / \mathrm{mol}^{(16)}$ に比較的近い值である. 以上の検討から, 微細な $\mathrm{Cr}_{2} \mathrm{O}_{3}$ 粒の還元は黒鉛粒周囲に形成された生成物 層における固体拡散速度によって支配されていると結論で きる。

粗粒試料では, 還元が $\mathrm{Cr}_{2} \mathrm{O}_{3}$ 粒の表面から内部へ，す なわちトポケミカルに進行している，炭材内装ペレットの 還元ではクロマイト粒子がトポケミカルに還元され，気孔 内拡散抒よび化学反応の混合律速として解析されてい $3^{(12)} . \mathrm{Cr}_{2} \mathrm{O}_{3}$ 粒子の周囲に形成された還元層の気孔率沶 よび気孔径は高温であるほど小さくなり，気孔内拡散の抵 抗が大きくなると考えられる．高温域で還元を行なった本 実験結果については, 式(13)の気孔内拡散律速式を用いて 速度解析を行なった。

$$
3-2 R-3(1-R)^{2 / 3}=k_{0}^{\prime} \cdot t
$$

ここに $R$ は $\mathrm{Cr}_{2} \mathrm{O}_{3}$ の還元率 $(=\% R / 100)$ である.

Fig. 12 は上記速度式の適用例を示す. 誘導期を経た後, $\% R=70 \sim 80$ までの間に扔いて良好な直線関係が成立し ている. 高還元率域に抢いてプロットは直線関係より下方

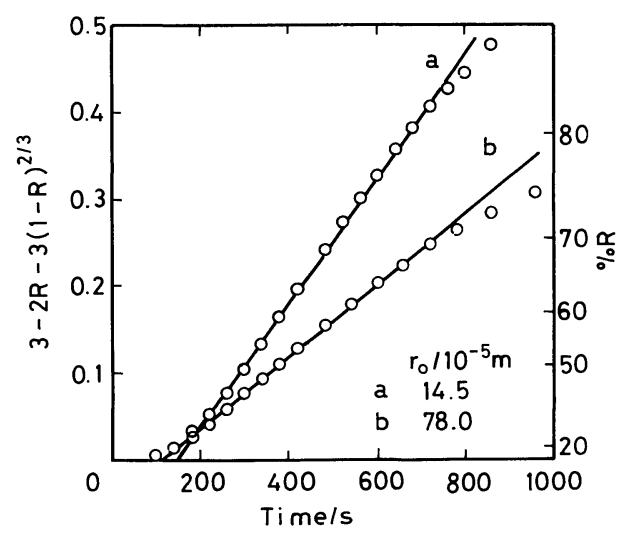

Fig.12 $3-2 R-3(1-R)^{2 / 3}$ vs time plots at $1893 \mathrm{~K}$ $\left(r_{\mathrm{c}}=5.8 \times 10^{-5} \mathrm{~m}\right)$. 
へ偏倚している.乙れは生成物層の緻密化・融体化が起乙 り(Fig.9(d)), ガスの拡散が困難になるととあに，式(13) の適用の前提条件を満足しなくなるためと考えられる. と ころで本来 $k_{\mathrm{o}}^{\prime}$ と $1 / r_{\mathrm{o}}^{2}$ との間に比例関係が成立するはず である.しかし Fig.12の結果に基づくと，乙の関係が得 られない. この理由の一つは $\mathrm{Cr}_{2} \mathrm{O}_{3}$ 粒子に存在する細孔 あるいは割れのため, 反応に関与する有効粒子径が $r_{0}$ と 異なるからである(13).

\section{V. 総 括}

$\mathrm{Ar}$ 雾囲気下, $1743 \mathrm{~K}$ 以上の高温で, 固体炭素による $\mathrm{Cr}_{2} \mathrm{O}_{3}$ の還元速度を測定した.

黒鉛るつぼ中で $\mathrm{Cr}_{2} \mathrm{O}_{3}$ を還元した場合，るつぼ壁と $\mathrm{Cr}_{2} \mathrm{O}_{3}$ との間に生成物層が形成される. 乙の生成物が $\mathrm{Cr}-$ $\mathrm{C}$ 融体として溶融する高温では還元が迅速に進行する。一 方, 生成物が固相となる温度では事実上還元が起らなかっ た。

つぎに $\mathrm{Cr}_{2} \mathrm{O}_{3}$ と黒鉛粒の配合試料を用いて還元を行なっ た結果は以下の通りである.

（1）黒鉛粒子の添加量が増加すると, 還元が著しく促進 される.しかし炭化物生成の当量配合比以上の過剰配合は 還元速度に影響を扣よぼさない。

(2) 黒鉛および $\mathrm{Cr}_{2} \mathrm{O}_{3}$ 粒子の粒径 $\left(r_{c}\right.$ および $\left.r_{o}\right)$ の増大 はいずれも還元速度の低下をむたらす。

(3) $r_{\mathrm{o}} \ll r_{\mathrm{c}}$ の場合には, 還元生成物は黒鉛粒の周囲に 形成される。早期より $\mathrm{CO}$ 発生反応はブードワ反応から炭 化物と $\mathrm{CO}_{2}$ との反応へ変化する. 速度式として放物線則 が適用できて, 緻密な生成物層を通しての固相拡散が律速
段階である。

(4) $r_{\mathrm{o}} \geqq r_{\mathrm{c}}$ の場合には, 酸化物粒子の周囲に生成物層 が形成され，還元がトポケミカルに進行する．黒鉛粒が生 成物によって被覆されていないので，還元末期までブード ワ反応が進行する. $\mathrm{Cr}_{2} \mathrm{O}_{3}$ 粒子側の気孔内拡散律速式を 適用することができた。

\section{文献}

（1）下尾聰夫, 磯部 勤, 安藤 繁, 木村 弘：日本金 属学会誌, 50(1986), 168.

（2）下尾聰夫, 磯部 勤, 安藤 繁, 木村 弘: 日本金 属学会誌, 50(1986), 646 .

（3）下尾聰夫, 安藤 繁, 木村 弘: 日本金属学会誌, $50(1986), 811$.

（4）下尾聰夫, 安藤 繁, 木村 弘: 日本金属学会誌, 51(1987), 439.

(5) H.Tagawa and H.Nakajima: Bull. Chem. Soc. Japan, 35(1962), 1239.

（6）殿村一男, 西村山治, 近藤良夫：水曜会誌, 15 (1966) , 502.

（7）北田杲三，宮下文涁，宮谷義六，三宅敏夫，松岡 山彦, 上山純生 : 日本金属学会誌, 40(1976), 187.

（8）片山' 博: 日本金属学会誌, 40(1976), 993.

（9）片山 博: 日本金属学会会報, 16(1977), 851.

（10）日本金属学会編: 金属データブック, 丸善, (1984), 446.

（11）月橋文孝，天辰正義，相馬胤和：鉄と鋼，68(1982), 1880 .

(12) 片山 博, 徳田昌則 : 鉄之鋼, 71(1985), 1607.

(13) Y.Maru, Y.Kuramasu, Y.Awakura and Y. Kondo : Met. Trans., 4(1973), 2591.

(14) 北田杲三，宮下文涁，宮谷義六，三宅敏夫，金子 豪: 日本金属学会誌, 44(1980), 728 .

(15) 北田杲三, 宮下文涁, 宮谷義六, 三宅敏夫, 金子 豪: 日本金属学会誌, 45(1981), 1236 .

(16) P.ギルダンク : 技術者の拡散入門，平野賢一，岡田 健 訳，共立出版，(1984), 88 。 